\title{
Correlation of Serum Markers and Ultrasound Markers in the Prediction of Threatened Miscarriage Outcome \\ Ali El-Shabrawy Ali ${ }^{1}$, Hala Elsayed Mowafy ${ }^{1}$, Mustafa Taha Abd El-Fattah ${ }^{1}$, Ibrahim Ali Ibrahim El-Gohary $2 *$ \\ ${ }^{1}$ Department of Obstetrics and Gynecology, Faculty of Medicine, Zagazig University, ${ }^{2}$ Department of Obstetrics and Gynecology Mit Ghamr General Hospital, Egypt \\ *Corresponding author: Ibrahim Ali Ibrahim El-Gohary, E-mail: monayahia92@gmail.com, Mobile: (+20) 1117991788
}

\begin{abstract}
Background: First-trimester bleeding is one of the most common obstetric complications, occurring in $25 \%$ of all pregnancies. The clinical diagnosis of threatened miscarriage is presumed when bloody vaginal discharge or bleeding appears through a closed cervical os during the first half of pregnancy.

Objective: The aim of the present study was to investigate the relationship between sonographic findings, progesterone level and serum CA-125 in women presenting with symptoms of threatened abortion and first trimesteric pregnancy outcome.

Subjects and Methods: This a case-control study included a total of 120 pregnant women between 7- and 13weeks' gestation in which a singleton embryo with evident cardiac activity was initially documented completed the study, attending at Gynecological and Obstetric Department in Zagazig University Hospital and Mit Ghamr General Hospital. This study was conducted between July 2016 to February 2018.

Results: There was no significant difference among groups in CRL and GSD but YSD was significantly higher among cases. CA 125 was significantly higher in actual miscarriage with a level $47.9 \mathrm{IU} / \mathrm{ml}( \pm 31.52)$ between those who had actual miscarriage before 13 weeks and $17.4 \mathrm{IU} / \mathrm{ml}( \pm 10.67)$ between those who continued pregnancy after 13 weeks while progesterone showed level $11.1 \mathrm{ng} / \mathrm{ml}( \pm 10.38)$ between those who aborted before 13 weeks and a level of $11.6 \mathrm{ng} / \mathrm{ml}( \pm 6.19)$ between those who continued. GSD and YSD significantly higher in actual miscarriage as the mean was $51.4 \mathrm{~mm}( \pm 18.56)$ and $6.73 \mathrm{~mm}( \pm 0.6)$ respectively for those who aborted and $38.52 \mathrm{~mm}$ and $6.11 \mathrm{~mm}$ respectively for those who continued pregnancy.

Conclusion: The use of ultrasound and maternal serum CA-125in the first trimester represents non-invasive, early and fast methods that can be considered as a good predictor for the outcome of pregnancy in cases with threatened abortion.
\end{abstract}

Keywords: Miscarriage, progesterone, CA-125, GSD, CRL, YSD.

\section{INTRODUCTION}

Missed abortion (MA) is diagnosed when a pregnancy ceases to develop, but there is a delay in the expulsion of the products of conception. MA is a complication of early pregnancy that occurs in $\leq 15 \%$ of all clinically recognized pregnancies ${ }^{(1)}$. Various risk factors have been established, such as age extremes (more commonly > 35 years), prior miscarriage, prolonged exposure to stress, abnormalities in uterine anatomy (presence of adhesions or tumors) and use of substances like cigarettes, alcohol, and certain drugs (2).

Serum progesterone measured in early pregnancy is the most powerful single predictor of pregnancy outcome in natural conceptions ${ }^{(3)}$. It is essential to study women after natural conceptions without exogenous progesterone support, when the relation between serum progesterone and viability of the first trimester pregnancy was evaluated ${ }^{(4)}$.

Lower progesterone levels prior to miscarriage, low body mass index but also obesity have shown to be significant risk factors as well ${ }^{(5)}$. Serum cancer antigen 125 (CA-125) and serum progesterone values measured alone or in various combinations, have proven helpful in ascertaining if a live intrauterine pregnancy is present ${ }^{(6)}$.

Ultrasonography, particularly the transvaginal technique, is the most important tool in the evaluation of early pregnancy or missed miscarriage. It permits direct examination of the products of conception in utero, eluding any damage caused during their natural expulsion or surgical evacuation ${ }^{(7)}$.

Several studies looked into the variations in size and shape of the gestational sac and/or the embryo-fetus incases of miscarriage (8). Nonetheless, the yolk sac (YS), the first ultrasonographically evident structure within the gestational sac, has been studied less intensively. The YS is usually identifiable as a round structure, made up of an anechoic center, and bordered by anechogenic, round, regular and well-defined rim.It is the primary source of fetomaternal exchange before the establishment of placental circulation ${ }^{(9)}$.

Its functions include nutritional, metabolic, hematopoietic, endocrine, and immunologic roles during early embryonic development ${ }^{(\mathbf{1 0})}$. Bagratee 
et al. (11) set the reference value for the YS size, which progressively increases up to a maximum at 10-11 weeks, then decreases afterwards. Changes in YS morphology probably reflect an abnormal embryonic development, rather than being a primary cause of miscarriage ${ }^{(\mathbf{1 2})}$.

This has previously helped either in predicting miscarriage or diagnosing its cause ${ }^{(8)}$. Effective screening can be achieved by measurement of the uterine artery plasticity index (PI) at 11-13 weeks of gestation, used in combination with maternal history ${ }^{(\mathbf{1 3})}$.

The aim of the present study was to investigate the relationship between sonographic findings, progesterone level and serum CA-125 in women presenting with symptoms of threatened abortion and first trimester pregnancy outcome.

\section{SUBJECTS AND METHODS}

This a case-control study included a total of 120 pregnant women between 7- and 13-weeks' gestation in which a singleton embryo with evident cardiac activity was initially documented completed the study, attending at Gynecological and Obstetric Department in Zagazig University Hospital and Mit Ghamr General Hospital. This study was conducted between July 2016 to February 2018.

Ethical approval and written informed consent: An approval of the study was obtained from Zagazig University Academic and Ethical Committee. Every patient signed an informed written consent with explanation of the strategy of research and for acceptance of the operation.

The included subjects were divided into two groups; Group 1 (control) consisted of 60 pregnant women with uneventful pregnancy without any problem and Group 2 (patients) consisted of 60 pregnant women with threatened abortion, of them; 21 cases ended by abortion (35\%) and 39 cases $(65 \%)$ continued till 20 weeks of gestation.

This study was set up to determine the accuracy of biochemical markers (CA-125 and progesterone) and ultrasound markers in the prediction of threatened miscarriage outcome.

\section{Exclusion criteria included:}

1. History of general medical disease e.g. diabetes, thyroid disease or antiphospholipid syndrome, Presence of local (gynecological) disease e.g. fibroid or adnexal masses verified by normal appearance of the uterus and ovaries by ultrasound.

2. Presence of uterine malformations e.g. hypoplastic uterus or septate uterus diagnosed by history of recurrent miscarriage, hysterosalpingography or 3D ultrasound, Intake of natural or synthetic progesterone.

3. Exposure to local trauma (Abdominal or sexual).

4. Patients with history of any maternal disease that would cause an increase in CA-125 level such as chronic pelvic infection, endometriosis and pelvic malignancy.

\section{Statistical analysis}

Recorded data were analyzed using the statistical package for social sciences, version 20.0 (SPSS Inc., Chicago, Illinois, USA). Quantitative data were expressed as mean \pm standard deviation (SD). Qualitative data were expressed as frequency and percentage.

\section{The following tests were done:}

- Independent-samples t-test of significance was used when comparing between two means.

- Chi-square $\left(\mathrm{x}^{2}\right)$ test of significance was used in order to compare proportions between two qualitative parameters.

- The confidence interval was set to $95 \%$ and the margin of error accepted was set to $5 \%$. The pvalue was considered significant as the following:

- Probability (P-value)

- P-value <0.05 was considered significant.

- P-value <0.001 was considered as highly significant.

- P-value >0.05 was considered insignificant. 


\section{RESULTS}

Table (1): Patients' Characteristics $(n=120)$ which shows no significant difference between groups regard maternal age, BMI, gestational age, residence and parity.

\begin{tabular}{|c|c|c|c|c|}
\hline \multicolumn{2}{|c|}{ 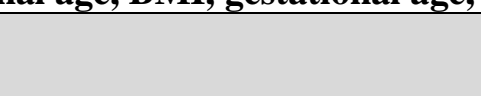 } & $\begin{array}{l}\text { Cases } \\
(60)\end{array}$ & $\begin{array}{l}\text { Control } \\
(60)\end{array}$ & $\begin{array}{l}\text { P- } \\
\text { value }\end{array}$ \\
\hline \multicolumn{2}{|c|}{$\begin{array}{l}\text { Maternal age (years) } \\
\text { Mean }( \pm S D)\end{array}$} & $27.05( \pm 3.31)$ & $26.5( \pm 4.01)$ & 0.414 \\
\hline BMI $\left(\mathrm{kg} / \mathrm{m}^{2}\right)$ & Mean $( \pm S D)$ & $26.5( \pm 2.96)$ & $26.3( \pm 3.59)$ & 0.555 \\
\hline \multicolumn{2}{|c|}{$\begin{array}{l}\text { Gestational age (weeks) at } \\
\text { time of recruitment } \\
\text { Mean }( \pm \mathrm{SD})\end{array}$} & $9.2( \pm 1.79)$ & $9.00( \pm 2.13)$ & 0.58 \\
\hline \multirow{2}{*}{ Residence } & Rural & $48(80 \%)$ & $42(70 \%)$ & \multirow{2}{*}{0.21} \\
\hline & Urban & $12(20 \%)$ & $18(30 \%)$ & \\
\hline \multirow{5}{*}{ Parity } & nulliparous & $15(25.0 \%)$ & $12(20.0 \%)$ & \multirow{5}{*}{0.85} \\
\hline & Para 1 & $18(30 \%)$ & $18(30 \%)$ & \\
\hline & Para 2 & $12(20 \%)$ & $12(20 \%)$ & \\
\hline & Para 3 & $12(20 \%)$ & $12(20 \%)$ & \\
\hline & Para 4 & $3(5 \%)$ & $8(10 \%)$ & \\
\hline
\end{tabular}

Results show that there was actual miscarriage significantly higher in threatened miscarriage group as it had a percent of $35 \%$ among cases and $15 \%$ among controls who all were presented with threatened abortion as shown in figure (1).

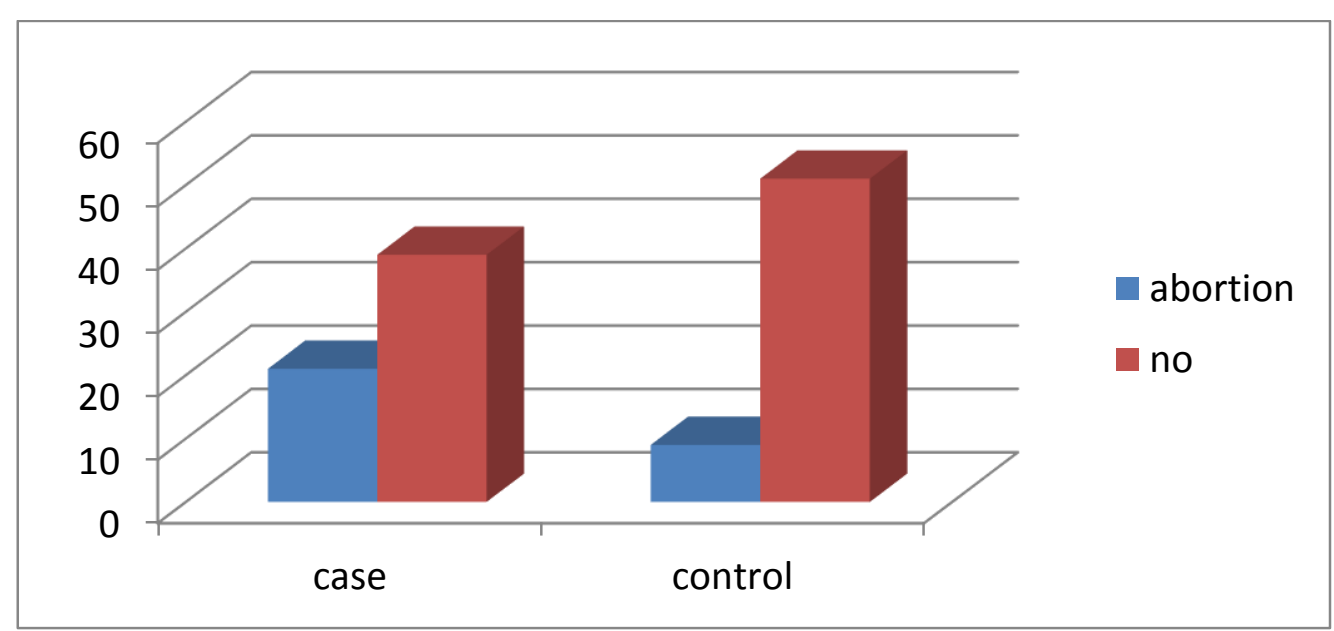

Fig. (1): shows actual miscarriage in the studied groups.

Results show that on comparison between study cases in relation to study parameters, CA-125 level was significantly higher in cases as compared with the control $(35.06 \mathrm{IU} / \mathrm{ml}( \pm 19.76) \mathrm{vs.} 15.05 \mathrm{IU} / \mathrm{ml}( \pm 9.85)$, $\mathrm{P}<0.001)$. Also, serum progesterone level was significantly lower in cases as compared with the control $(8.02 \mathrm{ng} / \mathrm{ml}( \pm 4.69)$ vs. $14.91 \mathrm{ng} / \mathrm{ml}( \pm 7.36), \mathrm{P}<0.001)$ (table 2$)$.

Table (2): CA 125 and Progesterone levels among cases and control.

\begin{tabular}{|l|l|l|l|}
\hline & Cases $(60)$ & Control $(60)$ & P \\
\hline $\begin{array}{l}\text { CA_125 (IU/ml) } \\
\text { Mean }( \pm \text { SD) }\end{array}$ & $35.06( \pm 19.76)$ & $15.05( \pm 9.85)$ & $0.001^{* *}$ \\
\hline $\begin{array}{l}\text { Progesterone level }(\mathbf{n g} / \mathbf{m l}) \\
\text { Mean }( \pm \text { SD) }\end{array}$ & $\mathbf{8 . 0 2}(\mathbf{\pm 4 . 6 9 )}$ & $\mathbf{1 4 . 9 1 ( \pm 7 . 3 6 )}$ & $0.001^{* *}$ \\
\hline
\end{tabular}

Our study showed that there was no significant differences among groups in CRL and GSD but YSD was significant higher among cases as shown in table (3) 
Table (3): Difference in CRL, GSD and YSD between cases and control groups.

\begin{tabular}{|c|c|c|c|c|c|c|}
\hline 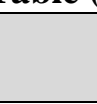 & Group & $\mathbf{N}$ & Mean & $\begin{array}{l}\text { Std. } \\
\text { Deviation }\end{array}$ & $\begin{array}{l}\text { t/ Mann } \\
\text { Whitney }\end{array}$ & $\mathbf{P}$ \\
\hline \multirow{2}{*}{ CRL } & Cases & 60 & 23.81 & 11.2 & \multirow{2}{*}{-0.46} & \multirow[b]{2}{*}{0.64} \\
\hline & Controls & 51 & 24.84 & 12.22 & & \\
\hline \multirow{2}{*}{ GSD } & Cases & 60 & 42.12 & 15.04 & \multirow{2}{*}{0.38} & \multirow{2}{*}{0.69} \\
\hline & Controls & 54 & 40.96 & 16.91 & & \\
\hline \multirow{2}{*}{ YSD } & Cases & 60 & 6.37 & 0.52 & \multirow{2}{*}{2.01} & \multirow{2}{*}{$0.05 *$} \\
\hline & Controls & 42 & 6.13 & 0.24 & & \\
\hline
\end{tabular}

Our study showed that CA 125 significantly higher in actual miscarriage with a level $47.9 \mathrm{IU} / \mathrm{ml}$ between those who had actual miscarriage before 13 weeks and $17.4 \mathrm{IU} / \mathrm{ml}$ between those who continued pregnancy after 13 weeks while progesterone showed level $11.1 \mathrm{ng} / \mathrm{ml}$ between those who aborted before 13 weeks and a level of $11.6 \mathrm{ng} / \mathrm{ml}$ between those who continued as shown in table (4).

Table (4): Progesterone and CA 125 level among actual miscarriage before 13 weeks and continued pregnancy after 13 weeks.

\begin{tabular}{|l|l|l|l|}
\hline & $\begin{array}{l}\text { Actual miscarriage } \\
\text { before 13 weeks } \\
(\mathbf{n}=\mathbf{3 0})\end{array}$ & $\begin{array}{l}\text { Continued Pregnancy after } \\
\mathbf{1 3} \text { weeks } \\
(\mathbf{n = 9 0})\end{array}$ & $\mathbf{P}$ \\
\hline $\begin{array}{l}\text { Progesterone level }(\mathbf{n g} / \mathbf{m l}) \\
\text { Mean }( \pm \text { SD })\end{array}$ & $11.1( \pm 10.38)$ & $11.6( \pm 6.19)$ & 0.76 \\
\hline $\begin{array}{l}\text { CA_125 }(\mathbf{I U} / \mathbf{m l}) \text { Mean } \\
( \pm \text { SD })\end{array}$ & $47.9( \pm 31.52)$ & $17.4( \pm 10.67)$ & $0.00^{* *}$ \\
\hline
\end{tabular}

Our study showed that GSD and YSD significantly higher in actual miscarriage as the mean was $51.4 \mathrm{~mm}$ and $6.37 \mathrm{~mm}$ respectively for those who aborted and $38.52 \mathrm{~mm}$ and $6.11 \mathrm{~mm}$ respectively for those who continued pregnancy as shown in table (5)

Table (5): $P$ value of CRL, GSD and YSD in actual miscarriage before 13 weeks and continued pregnancy after 13 weeks.

\begin{tabular}{|l|l|l|l|}
\hline & $\begin{array}{l}\text { Actual miscarriage before } \\
\mathbf{1 3} \text { weeks } \\
(\mathbf{n}=\mathbf{3 0})\end{array}$ & $\begin{array}{l}\text { Continued pregnancy after 13 } \\
\text { weeks } \\
(\mathbf{n = 9 0})\end{array}$ & $\mathbf{P}$ \\
\hline $\begin{array}{l}\text { CRL }(\mathbf{m m}) \text { Mean } \\
( \pm \text { SD })\end{array}$ & $27.46( \pm 16.55)$ & $23.26( \pm 9.46)$ & 0.10 \\
\hline $\begin{array}{l}\text { GSD }(\mathbf{m m}) \text { Mean } \\
( \pm \text { SD })\end{array}$ & $51.40( \pm 18.56)$ & $38.52( \pm 13.72)$ & $0.00^{* *}$ \\
\hline $\begin{array}{l}\text { YSD }(\mathbf{m m}) \text { Mean } \\
( \pm \text { SD })\end{array}$ & $6.73( \pm 0.6)$ & $6.11( \pm 0.23)$ & $0.00^{* *}$ \\
\hline
\end{tabular}

\section{DISCUSSION}

This study showed no statistically significant differences between the two studied groups as regard patient characteristics (maternal age, BMI, gestational age, residence and parity). These findings running in agreement with those results of Dadkhah et al. ${ }^{(14)}$.

Our study shows that actual miscarriage was significantly higher in threatened miscarriage group as in cases it was 21/60 (35\%) and in controls it was $9 / 60(15 \%)$.
Falco et al. ${ }^{(15)}$ investigated the relationship between sonographic findings and the occurrence of abortion between two groups with threatened abortion one continued and the other aborted. In both fetal cardiac activities was documented upon admission. The prevalence of abortion was 23/149 $(15 \%)$.

Oun et al. (16) compared two groups with threatened miscarriage continued and the other aborted and reported that $78.2 \%$ of the study group continued their pregnancy and $21.8 \%$ aborted. 
In our study found Cases were significantly higher regard CA 125 and significantly lower regard progesterone level.

Results show that on comparison between study cases in relation to study parameters, CA-125 level was significantly higher in cases as compared with the control $(35.06 \mathrm{IU} / \mathrm{ml}( \pm 19.76)$ vs. $15.05 \mathrm{IU} / \mathrm{ml} \quad( \pm 9.85), \quad \mathrm{P}<0.001)$. Also, serum progesterone level was significantly lower in cases as compared with the control $(8.02 \mathrm{ng} / \mathrm{ml}( \pm 4.69)$ vs. $14.91 \mathrm{ng} / \mathrm{ml}( \pm 7.36), \mathrm{P}<0.001)$.

This is running in agreement with Sweed $\boldsymbol{e t}$ al. ${ }^{(17)}$ who conducted a study between 120 women with threatened abortion (cases) and 60 women with nopast or present historyof bleeding in current pregnancy (controls). CA125 showed a statistically significant difference between the study groups as mean was 25.45 versus. $35.1 \mathrm{IU} / \mathrm{ml}$ for controls versus cases respectively.

Hamed et al. ${ }^{(18)}$ conducted a prospective study between a group f 80 pregnant women with normal cycles before pregnancy 41 of them, were primigravida (controls) and 39 with previous history of abortion (cases). They reported that serum CA125 was higher in the threatened miscarriage group as (mean values were 23.26 $( \pm 2.29) \mathrm{IU} / \mathrm{ml}$ ) and (mean values were 19.21 $( \pm 1.37) \mathrm{IU} / \mathrm{ml})$ in the control group and for progesterone it showed lower levels in pregnant with previous abortion as mean values were $(26.55$ $( \pm 1.36) \mathrm{IU} / \mathrm{ml})$ and in primigravida group they were $(32.46( \pm 2.07) \mathrm{IU} / \mathrm{ml})$.

In our study, there was no significant difference between groups regarding GSD 42.13 $( \pm 15.04)$ for cases and $40.96( \pm 16.92)$ for controls and CRL23.81 $( \pm 11.20)$ for cases and $(24.85$ $( \pm 12.23)$ for controls but YSD $6.38( \pm 0.52)$ for cases and $6.13( \pm 0.24)$ for controls shows difference as cases were significant higher.

The upper limit of normal yolk sac diameter in the early first trimester is approximately $4.5 \mathrm{~mm}$ when measured inner-inner ${ }^{(\mathbf{1 9})}$, and $6 \mathrm{~mm}$ when measured outer-outer ${ }^{(20)}$. A large yolk sac is an indicator of poor prognosis. Although the causal relationship between a large yolk sac and pregnancy prognosis is unclear, a number of studies have documented a high rate of pregnancy failure when the diameter of the yolk sac of $7 \mathrm{~mm}$ (19).

A study conducted by Oun et al. (16) compared between two groups with threatened abortion one continued and the other aborted. They reported that there was no significant difference between groups regarding gestational age by ultrasound and the crown rum length which agree with our study. In contrast to gestational sac diameter as there was statistically significant increase in who continued pregnancy to those who aborted ( $3.57 \pm 0.49$ vs. $3.10 \pm 0.27 \mathrm{~cm}$ respectively)

Oh et al. (21) measured gestational sac diameter during the 4th and 5th weeks of gestation from the last menstrual period in 67 women who had a total of 102 ultrasound scans. These pregnancies were followed until one of two outcomes occurred: term gestation $(\mathrm{n}=32)$ or spontaneous miscarriage $(n=35)$. They found that the mean diameter of the gestational sac among normal pregnancies did not differ significantly from that in those that subsequently miscarried (2.6 $\mathrm{mm}$ vs. $2.7 \mathrm{~mm}$ ).

In our study shows that Serum CA-125 levels were higher in threatened abortion aborted group (mean values were $47.9( \pm 31.52) \mathrm{IU} / \mathrm{ml})$ than continued group (mean value $17.4 \quad( \pm 10.67)$ $\mathrm{IU} / \mathrm{ml}$ ), there was a significant difference between each of the threatened abortion aborted and continued groups as ( $\mathrm{p} 0.00$ ).

These results are running in agreement with most studies Ayaty et al. (22) conducted a prospective case study carried out on 50 healthy pregnant (group 1) and 50 threatened abortion women (group 2). They compared the levels of CA-125 in these groups and followed them to be informed of the outcome of pregnancy.

The mean level of CA-125 in group 1 was $26.2 \pm 3.25 \mathrm{IU} / \mathrm{ml}$ and in group 2 was $37.44 \pm 2.72$ $\mathrm{IU} / \mathrm{ml}$. The mean level of CA-125 in finally aborted patients was $58.17 \pm 7.25 \mathrm{IU} / \mathrm{ml}$ and in normal pregnant women, who continued to term, was $26.61 \pm 1.76 \mathrm{IU} / \mathrm{ml}$. The CA-125 level in threatened women, whose pregnancy continued and did not abort, was $30.89 \mathrm{IU} / \mathrm{ml}$.

There was statistically significant difference between mean serum CA-125 in the patients, whose pregnancy was terminated before 20th week of gestation, $(58.7 \pm 7.25 \mathrm{IU} / \mathrm{ml})$ and in on-going pregnancy group $(26.61 \pm 1.76 \mathrm{IU} / \mathrm{ml})(\mathrm{p}=0.000)$.

In threatened abortion group (group 2), the final mean serum CA-125 level in aborted cases (12 cases) was $58.17 \pm 7.25 \mathrm{IU} / \mathrm{ml}$ and in those with on-going pregnancy after 20th weeks of gestation (38 cases), was $30.89 \pm 2.93 \mathrm{IU} / \mathrm{ml}$ Therefore, there was a significant difference between these two groups as well $(\mathrm{p}<0.01)$.

Fiegler et al. ${ }^{(23)}$ reported that a single serum CA-125 level determination is valuable in women with imminent abortion presenting with abdominal pain, vaginal bleeding or both. Kaminski et al. ${ }^{(24)}$ reported that women with threatening abortion revealed higher values of serum CA 125 antigen 
than those in control groups. The patients who had presented the highest values of the antigen later miscarried. Schmidt et al. (25) reported that sequential determinations of maternal CA 125 measurements appear to be a highly sensitive prognostic marker in patients with viable pregnancy at risk for abortion, while single serum measurements of CA 125 in symptomatic first trimester pregnant patients failed to discriminate spontaneous, missed, threatened abortion, ectopic or normal pregnancies. In Ocer et al. ${ }^{(26)}$ study, the prognostic predictive value of maternal serum CA125 measurement was investigated in 25 cases of threatened abortion and 25 healthy pregnant women. In serial measurements the mean serum CA125 level of the patients with an unfavourable pregnancy outcome was significantly higher than that of the patients with a favourable outcome. These findings suggest that the maternal serum CA125 measurement in threatened abortion can be useful to determine the extent of decidual destruction which is directly related to the outcome of pregnancy.

The results of this study disagreed with Mahdi (27). Forty-two pregnant women were recruited in this study. Their ages ranged from 1633 years old (mean 23 years), gravidity ranged ( 1 6) (mean 2.51). Number of previous abortions was (0-3) (mean 0.55). All of them were not smoker. the measurement of CA-125 showed higher mean value for the group that ended with abortion (39.9 \pm 15.4 ), in relation to the other group that continued pregnancy $(20.03 \pm 4.5)$ there was no significant difference between two groups in spite of its higher level in aborted group and this may refer to the little number of the patients included in the study.

In our study also shows the possible role of serum progesterone measurement in the prognosis of first trimester miscarriage. Serum progesterone levels were nearly the same in threatened abortionContinued Pregnancy after 13 weeks (mean values were $11.6( \pm 6.19) \mathrm{IU} / \mathrm{ml})$ as actual miscarriage before 13 weeks (mean value 11.1 $( \pm 10.38) \quad \mathrm{IU} / \mathrm{ml})$ according to the statistical analysis, there was no significant difference between each of the threatened abortion aborted and continued groups as $(\mathrm{p}=0.756)$.

This disagrees with the result of Edwar et al. (28) study of 78 pregnant women presented by vaginal bleeding 44 continued till 13th week of pregnancy and 34 ended with spontaneous abortion. Serum progesterone level was $5.7+10.9$ in continuing pregnancy and $6.7+4.8$ in spontaneous abortion. The difference in progesterone level was highly significant ( $\mathrm{p}$ value $<0.000$ ).
The study of biochemical and ultrasonographic predictors of outcome in threatened abortion presented by Maged et al. ${ }^{(29)}$ showed a statistically significant difference between the study groups regarding the level of progesterone $20.4( \pm 6.78)$ $\mathrm{IU} / \mathrm{ml}$ in aborted group and $39.6( \pm 10.86)$ in continuing pregnancy group.

Hamed et al. ${ }^{(18)}$ reported that progesterone was lower in aborted group $19.51( \pm 2.66)$ than in continuing pregnancy group $35.29( \pm 2.16)$, with $\mathrm{P}=0.004$ which is highly significant.

This disagreement caused as in our study progesterone was measured just one time at the time of recruitment while its regular measurement more than once shows its significance.

Our study showed that Abortion is associated with high parity and was not affected by either maternal age $28.40( \pm 3.38)$ for Actual miscarriage before 13 weeks group $26.23 \quad( \pm 3.62)$ for Continuing pregnancy after 13 weeks group, residence or BMI 28.68 ( \pm 2.48$)$ for Actual miscarriage before 13 weeks group $25.95 \quad( \pm 3.56)$ for Continuing pregnancy after 13 weeks group.

This agrees with Oun et al. ${ }^{(16)}$ who reported that maternal age was $25.96( \pm 2.14)$ in those continued pregnancy and $26.75( \pm 2.98)$ in those who aborted but disagree regarding parity as their study showed no significance.

\section{CONCLUSION AND RECOMMENDATIONS}

The use of ultrasound and maternal serum

CA-125 in the first trimester represent noninvasive, early and fast methods that can be considered as a good predictor for the outcome of pregnancy in cases with threatened abortion.

\section{REFERENCES}

1. Le J (2008): Obstetrics and Gynecology. 7th edition. People's Medical Publishing House; Beijing(In Chinese).

2. Maconochie N, Doyle P, Prior S et al. (2007): Risk factors for first trimester miscarriage-results from a UK-population-based case-control study, BJOG., 114: 170-186.

3. Elson J, Salim R, Tailor A et al. (2003): Prediction of early pregnancy viability in the absence of an ultrasonically detectable embryo. Ultrasound Obstet Gynecol., 21 (1):57-61.

4. Vicdan K, Zeki Isik A (2001): Luteal phase hormonal profile in prediction of pregnancy outcome after assisted reproduction. Eur J Obstet Gynecol Reprod Biol., 96 (1):98-101.

5. Arck PC, Ruecke M, Rose M et al. (2008). Early risk factors for miscarriage: a prospective cohort study in pregnant women. Reprod Biomed Online, 17:101 - 113 .

6. Rubio C, Simón C, Vidal F et al. (2003): Chromosomal abnormalities and embryo 
development in recurrent miscarriage couples. Hum Reprod., 18 (1):182-188.

7. Jeve Y, Rana R, Bhide A et al. (2011): Accuracy of first-trimester ultrasound in the diagnosis of early embryonic demise: A systematic review. Ultrasound Obstet Gynecol., 38: 489-496.

8. Angiolucci M, Murru R, Melis G et al. (2011): Association between different morphological types and abnormal karyotypes in early pregnancy loss. Ultrasound Obstet Gynecol., 37: 219-225.

9. Jauniaux E, Johns J, Burton G (2005): The role of ultrasound imaging indiagnosing and investigating early pregnancy failure. Ultra-sound Obstet Gynecol., 25:613-624.

10. Pereda J, Niimi G (2008): Embryonic erythropoiesis in human yolk sac:Two different compartments for two different processes.Microsc Res Tech., 71:856-862.

11. Bagratee JS, Regan L, Khullar V et al. (2009): Reference intervals of gestational sac, yolk sac and embryo volumes using three-dimensional ultrasound. Ultrasound Obstet Gynecol., 34: 503509.

12. Kupesic S, Bekavac I, Bjelos D et al. (2001): Assessment of endometrial receptivity by transvaginal color Doppler and three-dimensional power Doppler ultrasonography in patients undergoing in vitro fertilization procedures. $\mathbf{J}$ Ultrasound Med., (20)125-134.

13. Nicolaides KH (2011): Turning the pyramid of prenatal care. Fetal Diagn Ther., 29:183-196.

14. Dadkhah F, Kashanian M, Eliasi G (2010): A comparison between the pregnancy outcome in women both with or without threatened abortion. Early Human Development, 86:193-196.

15. Falco P, Milano V, Pilu G et al. (1996): Sonography of pregnancies with first-trimester bleeding and a viable embryo: a study of prognostic indicators by logistic regression analysis. Ultrasound Obstet Gynecol., 7:165-9.

16. Oun AM, Ibrahem EM, Abd El-aziz MR (2018): Role of both serum CA-125 and ultrasund in redictin $f$ regnancy outcome $n$ first trimester miscarriage. Internatinal journal of life sciences, 7 (2): 97-84.

17. Sweed MS, Sammour HM, Bakr AA (2016): Serum CA-125 for Early Prediction of Miscarriage. Med J Obstet Gynecol., 4 (1): 1077.

18. Hamed M, Dawakhly $H$, Shaaban A et al. (2016): Predictive Value of the Triplemarkers:
Serum Progesterone, Ca 125 And Beta - Hcg For The Possible Occurrence Of Miscarriage. American Journal of Research Communication, 4 (6): 47-62.

19. Lindsay DJ, Lovett IS, Lyons EA et al. (1992): Yolk sac diameter and shape at endovaginal US: predictors of pregnancy outcome in the first trimester.

https://doi.org/10.1148/radiology.183.1.1549656.

20. Cepni I, Bese T, Ocal P et al. (1997): Significance of yolk sac measurements with vaginal sonography in the first trimester in the prediction of pregnancy outcome. Acta Obstet Gynecol Scand., 76: 969972.

21. Oh JS, Wright G, Coulam CB (2002): Gestational sac diameter in very early pregnancy as a predictor of fetal outcome. Ultrasound Obstet Gynecol., 20: 267-71.

22. Ayaty S, Roudsari F, Tavassoly A (2007): F: CA-125 in normal pregnancy and threatened abortion. Iranian Journal of Reproductive Medicine, 5 (2):57-60.

23. Fiegler P, Katz M, Kaminski K et al. (2003): Clinical value of a single serum CA-125 level in women with symptoms of imminent abortion during the first trimester of pregnancy. J Reprod Med., 48 (12):982-8.

24. Kaminski K, Zwirska-Korczala K, Fiegler $\mathbf{P}$ (2002): Level of CA-125 Ag in serum of first trimester normal and miscarried pregnancy. Wiad Lek., 55: 310-314.

25. Schmidt T, Rein D, Foth D et al. (2001): Prognostic value of repeated serum CA125 measurements in first trimester pregnancy. Eur J Obstet Gynecol Reprod Biol., 97: 168-173.

26. Ocer F, Ilese T, Saridogan E et al. (1992): The prognostic significance of maternal serum CA 125 measurement in threatened abortion. Eur J Obstet Gynecol Reprod Biol., 16:137-142.

27. Mahdi B (2010): Estimation of CA-125 Level in First Trimester Threatened Abortion. The internet Journal of Gynecology and Obstetrics. 12 (2): 9 (4): 506-511.

28. Edwar ZK, Mahasin MA, Suror A (2011): The value of early pregnancy single serum progesterone mesurment in relation to first trimester viability. Thi-Qar Medical Journal, 5 (2):133-141.

Maged AM, AI Mostafa W (2013): Biochemical and ultrasonographic predictors of outcome in threatened abortion. Middle East FertilSoc J., http://dx.doi.org/10.1016/j. 